ОЦІНОЧНО-КРИТЕРІАЛЬНИЙ МОНІТОРИНГ ДІЄВОСТІ СИНЕРГЕТИЧНО-РЕОРГАНІЗАЦІЙНОГО АЛГОРИТМУ МАКРОГЕНЕЗУ
«КАРТИНИ СВІТУ» ОСОБИСТОСТІ

\title{
EVALUATION AND CRITERIA MONITORING THE EFFICIENCY OF THE SYNERGETIC-REORGANIZATION ALGORITHM OF MACROGENESIS OF THE "PICTURE OF THE WORLD" PERSONALITIES
}

у статті висвітлюється система оціночно-критеріального моніторингу макрогенезу «картини світу» особистості. Визначено, що реорганізація «картини світу» детермінується експліцитно та імпліцитно заданими властивостями людини як складної системи до саморуху та еволюціонування через підвищення точності репрезентацій об'єктивного світу. Обгрунтовано дію синергетично-реорганізаційного алгоритму як багатокомпонентної системи прочесів перетворення, динаміки та розвитку особистості, руху ї життя. Представлено та описано п'ять інтегративних блоків синергетично-реорганізаційного алгоритму та елементи їх змістового наповнення. Побудована система оціночно-критеріального моніторингу макрогенезу «картини світу» особистості. Визначено критерії моніторингу: «співвіднесення зі світом» та «самовіднесення». Доведено необхідність об'єктивації зовнішніх і внутрішніх маркерів критеріїв моніторингу, які змістовно структурують процес «оновлення» смислового поля особистості, реорганізованого новими смисловими з'єднаннями. Обгрунтовано психологічні механізми макрогенезу «картини світу» в проєкціях практичноі діяльності, комунікації та самопородження. Доведено, що причинна та смислотвірна детермінації «картини світу» зумовлені принципом постійного зростання складності внутрішньої організації як результату неперервної динамічної взаємодії з умовами свого існування. Описано внутрішні маркери моніторингу макроґенезу «картини світу», які відображають контекстуальний план реорганізаційної дії та зосереджуються на розкритті, аналізі й розумінні власноі екзистенції, актуальних екзистенціальних переживань, знаходження автентичної позиції щодо конкретної ситуації. Визначено, що зовнішні маркери відображають фрункціональний план реорганізаційної дії та містять результати дій, оцінка яких характеризує перебіг та якість процесу змін. Диференційовано та описано одиниці оцінки внутрішніх та зовнішніх маркерів, які можуть бути використані як досліджувані ознаки з метою перевірки результативності дії синергетично-реорганізаційного алгоритму.

Ключові слова: екзистенціально-системний концепт, синергетично-реорганізаційний алгоритм, співвіднесення зі світом, самовіднесення, зовнішні маркери, внутрішні маркери, одиниці оцінки.
The article covers the system of evaluation and criterion monitoring of the macrogenesis of the individual "picture of the world". It is defined that the reorganization of the "picture of the world" is determined explicitly and implicitly by the given properties of man as a complex system to self-movement and evolution by increasing the accuracy of representations of the objective world. The action of synergetic-reorganization algorithm as a multicomponent system of processes of transformation, dynamics and development of personality, movement of its life is substantiated. Five integrative blocks of synergetic-reorganization algorithm and elements of their content are presented and described. A system of evaluation and criterion monitoring of the macrogenesis of the "picture of the world" of the individual is built. Monitoring criteria are defined: "correlation with the world" and "self-attribution". The necessity of objectification of external and internal markers of monitoring criteria, which substantively structure the process of "updating" the semantic field of the personality, reorganized with new semantic connections, is proved. Psychological mechanisms of macrogenesis of "picture of the world" in projections of practical activity, communication and self-generation are substantiated. It is proved that the causal and meaningful determinations of the "picture of the world" are due to the principle of constant growth of the complexity of the internal organization as a result of continuous dynamic interaction with the conditions of its existence. Internal markers for monitoring the macrogenesis of the "picture of the world" are described, which reflect the contextual plan of reorganization action and focus on the disclosure, analysis and understanding of their own existence, current existential experiences, finding an authentic position on a particular situation. It is determined that external markers reflect the functional plan of the reorganization action and contain the results of actions, the assessment of which characterizes the course and quality of the change process. The units of evaluation of internal and external markers are differentiated and described, which can be used as investigated features in order to check the effectiveness of the synergetic-reorganization algorithm.

Key words: existential-system concept, synergetic-reorganization algorithm, correlation with the world, self-attribution, external markers, internal markers, units of assessment.
Вступ. «Фрагмент екзистенціальної дійсності, 3 яким людина себе співвідносить та який значуще на неї впливає» - це континуально-дискретний конструкт, що відобра- жує індивідуальний процес життєвого руху 3 нескінченністю його вимірів, 3 «переплетенням у ньому різних ліній розвитку, кожна з яких має свою історію» $[11$, с. 5]. Просто- 
рові, часові, вітальні, ментальні та інформаційні спектри екзистенції людини виявляються в різноманітних аспектах життя і, зокрема, як вказує Ш. Бюлер, «в об’єктивній логіці життя, в послідовності зовнішніх і внутрішніх подій, в еволюції внутрішнього світу, зміні переживань й цінностей і в результатах діяльностей» [цит. за: 14, с. 29]. Відповідь на правомірне питання про головні рушійні сили життєвого процесу лежить у просторі дослідження життєвого шляху, «наявність якого означає, що особистість здолала екзистенціальну закинутість і стала людиною існуючою, тобто самостійно здійснюючою себе, своє життя» [11, с. 11]. Визнаючи факт невипадковості життя конкретної людини та можливості його феноменологічної розвідки в просторі функціональної, розуміючої психологічної парадигми (на відміну від пояснювальної) дослідники вводять поняття, релевантні рушійній силі макроґенезу особистості. Такими поняттями виступають: «самоздійснення» Ш. Бюлер; «самоактуалізація» Дж. Морено; «фасилітація самоорганізації» К. Роджерса; «самотворення» Л. Анциферової, «вчинкова самореалізація» В. Роменця; «створення власної історії» С. Рубінштейна; «баланс усвідомлення провідних цінностей та смислів і неусвідомлюваних переживань-рухів у особистості як у цілісності, що саморозвивається» С. Максименка; «самодетермінація та самоорганізація» Д. Леонтьєва; «самоускладнення» М. Чиксентмихайї; «збалансовані зв'язки між суб'єктивним та об'єктивним світами» Дж. Бьюдженталя тощо [11, с. 8-12; 8 , с. $97 ; 18$, с. $28 ; 2$, с. 185$]$.

«Фрагмент екзистенціальної дійсності людини» як результат співвіднесення себе з реальним світом відображує суб'єктивну модель реальності - «картину світу», яка $€$ системною особистісною моделлю, багатошаровою конструкцією суб'єктивних образів реального світу та смислових зв'язків між ними [5, с. 102]. «Картина світу» віддзеркалює цілісність парафернального узагальненого полюсу переживань особистості й формує смислове поле особистості, наповнене «мнемічними контекстами» і змістом ракур-

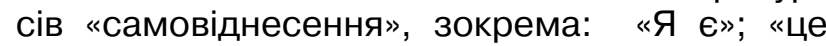
$\epsilon$ Я»; «це Мої переживання»; «це Мої думки»; «це Я роблю»; «це Моє життя зараз»; «це Мій досвід»; «це Мої уявлення про майбутнє» [6]. Зазначені ракурси - це проєкції та мінімоделі дійсності, які зумовлюють процес подальшого відбиття реальності з унікальними для людини зафіксованими головними координатними осями й пріоритетними точками, масштабом, топографією та типовою емоційною забарвленістю «картини світу» та її окремих елементів.

Аспекти мікрогенезу (становлення) та макроґенезу (розвитку) «картини світу» особистості доцільно розглядати із засто- суванням «транстеоретичної методології», загальними характеристиками якої виступають: багатоплановість, конвергенція, уніфікація часток, створення нового об'єднання $[15$, с. 16]. Запропонований нами транстеоретичний екзистенціально-системний концепт $€$ результатом застосування «поліфонічного» підходу до реорганізації суб'єктивної «картини світу» особистості в умовах «багатоголосся» психологічних систем надання допомоги клієнтам у психологічній практиці. Функціональний аспект та методичний потенціал екзистенціально-системного концепту розкривається через дію «реорганізації» як процесу взаємодії особистості з навколишнім середовищем через повторювальні патерни «співвіднесення зі світом» та «самовіднесення», кожен з яких запускає структурні зміни в системі, що актуально задіяна [6]. Реорганізація «картини світу» детермінується експліцитно та імпліцитно заданими властивостями людини як складної системи до саморуху та еволюціонування через підвищення точності репрезентацій об'єктивного світу, збільшення масштабу суб'єктивної моделі світу, складання «множинного тексту на всіх пізнавальних контурах: сенсорно-перцептивному, уявлень, мисленнєвому, афективному, рефлексивному» [1, с. 110].

Мета статті - висвітлити систему оціночно-критеріального моніторингу макрогенезу «картини світу» особистості.

Виклад основного матеріалу дослідження. Синергетично-реорганізаційний алгоритм - це багатокомпонентна система керованої психологом-консультантом трансформаційної дії «співвіднесення зі світом» та «самовіднесення» клієнта як процесів перетворення, динаміки та розвитку особистості, руху її життя, що здійснюється через переживання континууму станів і створення смислового поля, організованого зв'язками відповідного мнемічного контексту. Синергетично-реорганізаційний алгоритм складається з п'яти інтегративних блоків та елементів їх змістового наповнення (рис. 1).

1. Блок пізнавальних контурів (сенсорно-перцептивного, уявлень, мисленнєвого, афективного, рефлексії) виступає водночас і джерелом смислів, і тлом смислового поля, окреслює масштаб і специфіку «картини світу» клієнта та, як результат, забезпечує кінцеву мету психологічної допомоги - модифікацію екзистенціальних уявлень.

2. Блок конструкту «співвіднесення зі світом» (інтерпсихічний, інтрапсихічний, екзистенціальний і системний ракурси) створює змістовно-контекстну канву психологічної допомоги: окреслює проблемні та ресурсні зони клієнта, об'єктивує системні зв'язки, визначає причинну та смислову детермінованість, наслідки та ресурсні можливості. 


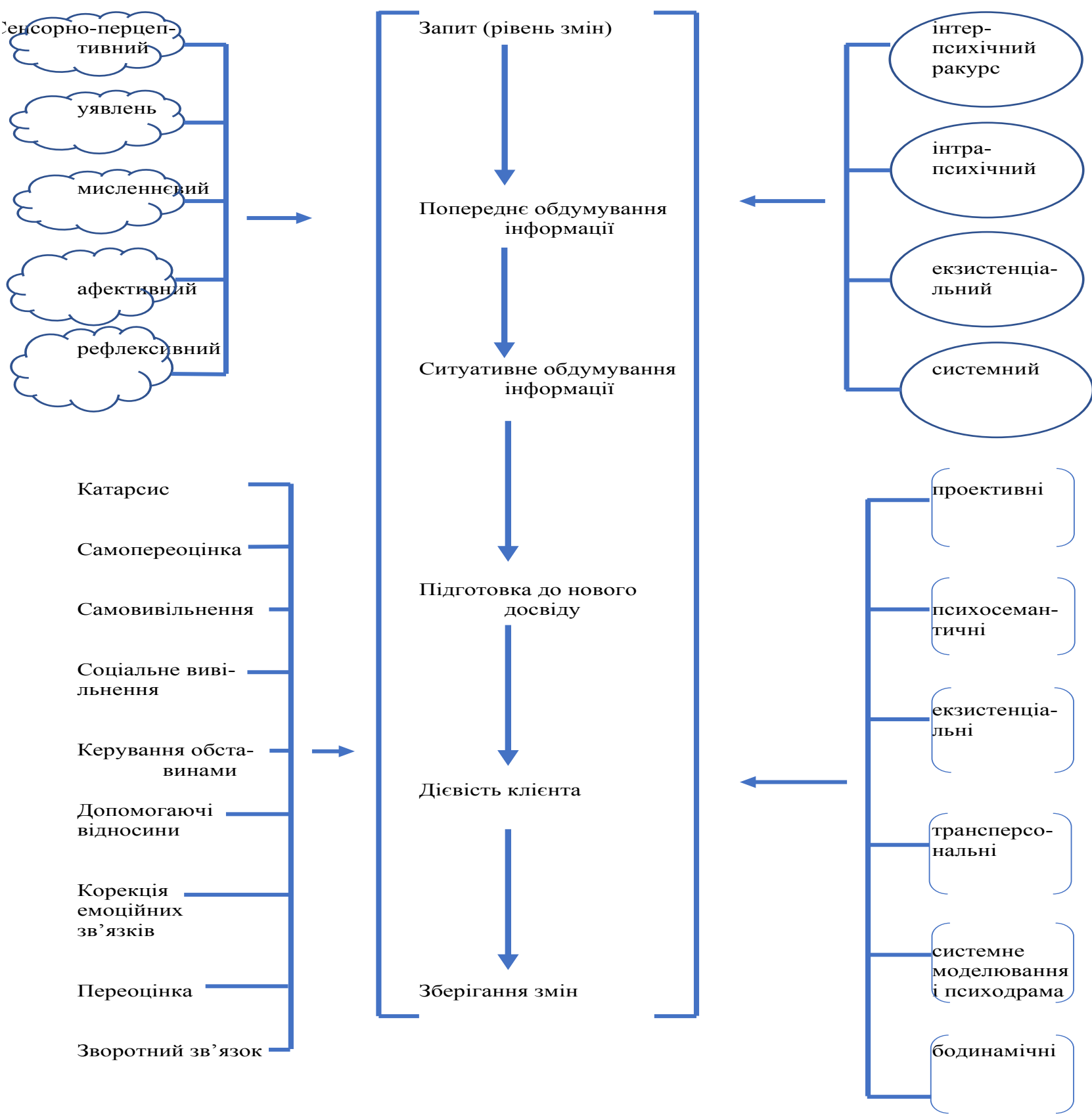

\section{Рис. 1. Узагальнена схема дії синергетично-реорганізаційного алгоритму макрогенезу «картини світу» особистості}

3. Навантаження блоку процесу змін (катарсис, самопереоцінка, самовивільнення, соціальне вивільнення, керування обставинами, допомогаючі відносини, корекція емоційних зв'язків, переоцінка, зворотний зв'язок) спрямовує дію «самовіднесення» та визначає актуалізацію результативних факторів: послаблення напруги на перших сесіях, розширення репертуару когнітивних схем, оперативну модифікацію поведінки, придбання нових соціальних навиків, оволодіння та відпрацювання адаптивних патернів поведінки. Блок характеризується проявом послідовних, варіативних та спіральних патернів внутрішніх та зовнішніх дій клієнта.
4. Діагностично-корекційний блок визначає засоби доступу до внутрішнього світу клієнта (проєктивний, психосемантичний, екзистенціальний, трансперсональний, бодинамічний підходи, системне моделювання та психодрама). Можливості діагностично-корекційних підходів забезпечують задіяність усіх пізнавальних контурів свідомості: сенсорно-перцептивного, наприклад: пропріоцептивного за допомогою методів бодинаміки, холотропного дихання та трансформаційної функції музики; уявлень - за допомогою екзистенціальних та проєктивних методів; мисленнєвого - психосемантичними методами; афективного - методами системного 
моделювання та психодрами; рефлексивного з використанням всіх методичних підходів.

5. Блок стадій змін (попереднє обдумування інформації, ситуативне обдумування інформації, підготовка до нового досвіду, дієвість клієнта, зберігання змін) - це об'єднувальний, стрижневий вектор, який віддзеркалює динаміку процесу та відстань до загальної мети розширення горизонту екзистенціальної дійсності клієнта.

Кожен елемент кожного блоку впливає на інші структурні складники алгоритму й зумовлює ступінь їх залученості в окремому випадку надання психологічної допомоги. Дія синергетично-реорганізаційного алгоритму забезпечує систематичний кругообіг: «картина світу» «смислове поле» «реорганізаційна дія» «функція переживання» «парадоксальний зв'язок смислів» оновлене «смислове поле» оновлена «картина світу». Реорганізаційна дія спрямовується на зону «фільтру переваги» («кристалізований» патерн», помилковий аттрактор), що дає змогу знайти втрачене клієнтом означаюче та означуване в парафернальному потоці переживань щодо або певного ракурсу екзистенціальної дійсності (наприклад, у разі симптому), або власної екзистенції загалом (наприклад, у разі втрати). Внутрішній ланцюг реорганізаційної дії - це послідовність операцій алгоритму: умови (змістовно-контекстний план) $\rightarrow$ інструмент (діагностико-корекційні методи й підходи) $\rightarrow$ переживання (катарсис, парадоксальність, подив), викликані процесами «співвіднесення зі світом» та «самовіднесення» (функціональний план) $\rightarrow$ смисли (парадоксальні зв'язки між смислами, їх упорядкування) $\rightarrow$ розширення деталізації смислового поля в задіяному пізнавальному контурі (сенсорно-перцептивному, уявлень, мисленнєвому, афективному, рефлексивному) та їх взаємодія $\rightarrow$ структурні зміни в смисловому полі, що приводять до оновлення «картини світ $\rightarrow$ у» особистості.

Моніторинг макрогенезу «картини світу» особистості передбачає визначення критеріїв синергетично-реорганізаційної дії та їх оцінку через об'єктивацію зовнішніх і внутрішніх маркерів, які змістово структурують процес «оновлення» смислового поля особистості, реорганізованого новими смисловими з'єднаннями.

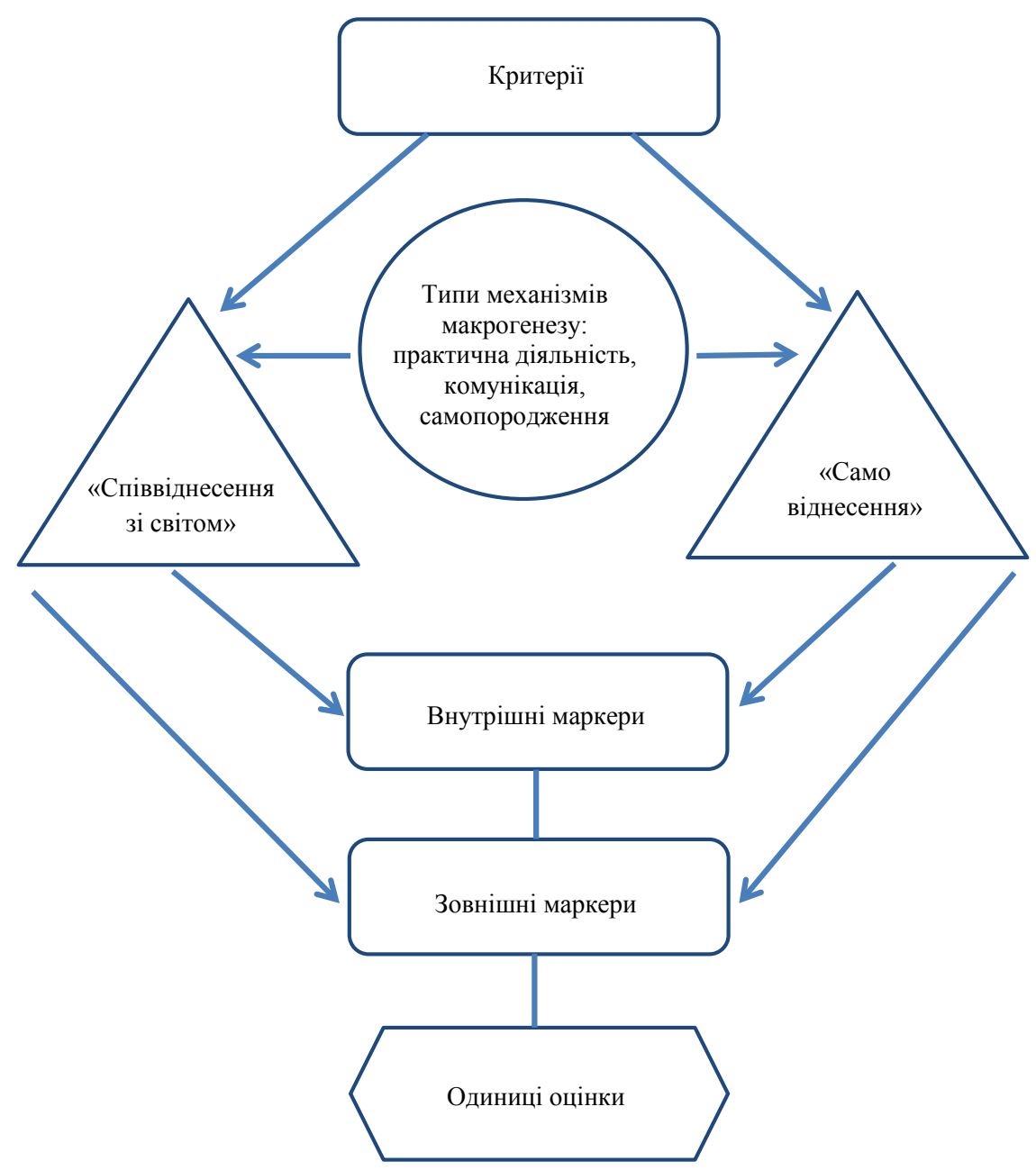

Рис. 2. Тло оціночно-критеріального моніторингу макрогенезу «картини світу» особистості 
На рис. 2 наведена площина оціночно-критеріального моніторингу, яка інтегрується функціональними, генетичними та детермінаційними зв'язками процесуальної реорганізації «картини світу» особистості.

Критерії моніторингу відтворюються двома центральними понятійними системами:

1. «Співвіднесення себе зі світом», яке розкриває багатоваріативність проявів мнемічних контекстів як власного досвіду та життєвого шляху в трьох аспектах, а саме в інтерпсихічному: «Я і особисті відношення», «Я і соціум», «Я і мої діяльності»; в екзистенціальному: «Я і Світ», «Я і моє Життя», «Я і життєві Події», «Я і Виклики життя», «Мої Інтенції»; в системному: «Елементи систем, до яких належу» (наприклад, члени родини; грані життєвого сприйняття; здоров'я та симптоми; ставлення до минулого, майбутнього та сьогодення тощо), «Емоції і стани, що пов'язують елементи систем», «Емоції й програми дій, які зумовлені емоціями та станами».

2. «Самовіднесення» як вагомий складник «співвідношення зі світом», його інтрапсихічний аспект, що розгортається в ракурсах: «Я є», «це є Я», «це Мої переживання», «це Мої думки», «це Я роблю», «це Моє життя зараз», «це Моє минуле», «це Мої уявлення про майбутнє», «це Мої Ресурси та Свобода», «це Моя Відповідальність». Інтрапсихічний аспект - це ракурси внутрішньої системи самодетермінації особистості, що саморегулюється, перебуває в динамічній взаємодії з навколишнім середовищем та еволюціонує через постійне зростання складності й внутрішньої організації з відкриттям парафернального смислу щодо власної свободи та відповідальності [8, с. $108 ; 13$, с. 205].

Обґрунтовуючи «психологічні механізми формування образу світу», В. Серкін підкреслює, що «індивідуальні образи світу, як і будьякі системи, не розвиваються "самі із себе» та «самі для себе» [16, с. 178]. Встановлення механізму розвитку «картини світу» передбачає врахування багатоплановості макрогенезу, зокрема, онтологічного, функціонального, генетичного, детермінаційного його планів та знаходження відповідей на парціальні питання: Що є «картина світу»? Як вона формується? Для чого? Яке призначення? На засаді чого? Чому? Навіщо? [16, с. 178]. Відповідь на питання: «Що є «картина світу»? зумовлена характером її зв'язку (сутністьформа) 3 поняттям «смислова архітектоніка свідомості особистості» як багатокомпонентної смислової конструкції психічного, що детермінується процесом розуміння свідомістю власного "тексту», конструюванням смислів окремої події через відношення до неї. «Картина світу», на наш погляд, є об'єктивацією смислової архітектоніки свідомо- сті, у формі «стабільно-динамічної» смислової моделі себе та світу. Загальний погляд на процес становлення (мікрогенезу) «картини світу» відображає онтологічний рух форм орієнтування та організації взаємодії з навколишнім середовищем, виокремлюючи «орієнтовно-дослідницькі операції, операції планування способу досягнення результату, виконавчі операції та операції контроля» [10, с. 51]. Обґрунтування функціонального аспекту (Для чого?) «картини світу» лежить у площині діяльнісного підходу, з позицій якого будь-яка складна система розглядається 3 урахуванням двох підсистем: регулятивної (мотивація, цілепокладання, оцінка значень) та орієнтовної (врахування умов, контроль, зворотний зв'язок, образ) [16, с. 178]. Розрізнення ядерних та поверхневих структур образу світу в роботах С. Смірнова та О. Леонтьєва розкриває процес руху макрогенезу «картини світу»: почуттєва форма поверхневих структур (модально оформлена) $\rightarrow$ раціональна форма, дія розуміння, відкриття смислу, надпочуттєві якості, значення, смисли (амодальна форма) [17, с. 20; 7, с. 9]. Рух макрогенезу здійснюється не від глибини (ядерних структур) до поверхових шарів - це рух від явища та його сутності (образ світу) до відкриття всіх можливих його граней, відкриваючи їх одна за одною («картина світу»). Це автопоезний рух, який спрямовано, з одного боку, на відображення дійсних зв'язків зі світом (життєві ситуації, життєві виклики), з іншого - на пізнання й розуміння світу з побудовою на засаді «самовіднесення» і співпричетності більш-менш глибокої «картини світу» 3 інтенціями вибору, свободи та відповідальності. Джерела та механізми макрогенезу «картини світу» (На засаді чого?) перебувають у плані внутрішньої діяльності, яка розглядається в трьох проєкціях:

- як практична діяльність - система взаємопереходів планів внутрішньої й практичної діяльності (інтеріоризація-екстеріоризація);

- як комунікація - внутрішній та зовнішній діалог, що зумовлює комбінаторні можливості внутрішнього плану діяльності й формування смислового поля;

- як самопородження - смислотворіння на всіх пізнавальних контурах (сенсорно-перцептивному, уявлення, мисленнєвому, афективному, рефлексії) [16, с. 179].

Причинна (Чому?) та смислотвірна (Навіщо?) детермінації «картини світу» зумовлені принципом постійного зростання складності внутрішньої організації як результату неперервної динамічної взаємодії з умовами свого існування та базується на системно-еволюційних ідеях М. Чіксентміхайї, що відбивають закономірність динаміки особистості через розвиток властивості подолання складності [18, с. 163]. 
Оцінка критеріїв синергетично-реорганізаційного алгоритму здійснюється за допомогою об'єктивації зовнішніх та внутрішніх маркерів, що змістово та функціонально розкривають поняття «співвіднесення зі світом» і «самовіднесення». Внутрішні маркери відображають контекстуальний план реорганізаційної дії та зосереджуються на розкритті, аналізі й розумінні власної екзистенції, актуальних екзистенціальних переживань, знаходження автентичної позиції щодо конкретної ситуації. До внутрішніх маркерів віднесено:

- соціально-культурний контекст (минуле, досвід, переконання, «Я повинен», Чому? Як правильно?);

- феноменологія життя (моє життя зараз, Я можу, теперішній час, Як? Чи можу це? Де?);

- уявлення про майбутнє (ідеї, перспективи, Я хочу, Куди йти? Чи хочу цього?);

- виклики життя: невизначеності, складності, резиґнації, вибору, різноманітності (Що змінилося? Чи є у мене тривога? Чи був у мене вибір? Що я відчуваю: сумніви чи рішучість?);

- переоцінку (цінності, Чому це важливо для мене?);

- простір (системи, об'єкти, Хто? Що?);

- думки (звичні, типові патерни розуміння, Як інтерпретую? Про що міркую?);

- переживання (звичні, типові емоційні патерни, Що відчуваю? Що мені треба? Що є моєю необхідністю зараз?);

- дії (звичні поведінкові патерни, Що я роблю? Як я це роблю?);

- це є Я (ідентичність, Хто Я?);

- «Я Є» (мої ресурсні стани, моє «призначення» в системах).

Зовнішні маркери відображають функціональний план реорганізаційної дії та містять результати дій, оцінка яких характеризує перебіг та якість процесу змін, а саме:

- елементи процесу змін, що сприяють реорганізації смислів через дії зростання усвідомлення, катарсису та вибору;

- елементи стадії змін віддзеркалюють темп і специфіку руху клієнта у консультативному процесі;

- одиниці аналізу зумовлюють можливість входження у світ клієнта, фокусування уваги та спрямованість логіки вирішення запиту;

- елементи контакту визначають зміст інтерпсихічного діалогу з психологом: аналіз почуттів; думок; ставлень; контекстуального компонента; тілесного компонента; ідіосинкразійного компонента;

- операційні техніки кожного з п'яти діагностико-корекційних підходів: проєктивного (методика «Мій світ» - модифікована методика «Хто Я?» М. Куна та Т. Макпартленда; ранжування цінностей з посиленим емоційним компонентом для визначення крапок аттракції системи досліджуваного); психосемантичного (семантичний аналіз порушень смислових утворень); екзистенціального («досвід зустрічі із собою, зі світом й іншими людьми»; «співвіднесення та діалогічний обмін між Я і світом»; усвідомлення базових механізмів дії «інтенціальності», «самотворення», «автентичності», «внутрішньої рівноваги», «свободи», «відповідальності», «трансцендентності»; усвідомлення внутрішнього діалогу - здійснення переходу від страху реакцій тіла до усвідомлення симптому як порушеного балансу між ваганням і відповідальністю й свободою вибору) [9, с. 28]; системного моделювання і психодраматичного підходу (моделювання і відреагування ситуацій, що мають вагому емоційну напругу; розпізнавання знайдених дисбалансів; побудова моделей «я і Життя»; відкриття парадоксального сенсу у разі виявлення переважних станів та програм дій, які генерує досліджуваний; генералізація «я»; визначення «супер-позиції»; «тріада»; «тетролемма»; квадрат «Да-Ні»; «контекст станів»; «подорож до глибинної мети»; «баланс між унікальністю і цінністю», «лінія життя» тощо з метою аналізу складників системи та виявлення неефективного вихідного аттрактору і знаходження тригеру) [4, с. 61]; бодинамічного підходу («Новий позитивний імпринтинг народження» з метою відкриття конденсованого досвіду та фіксованої установки імпринтингу народження як базової крапки біфуркації життя, як фундаменту формування емоційних і поведінкових патернів і специфічної емоційної забарвленості суб'єктивної моделі реальності [5, с. 63]); трансперсонального підходу (холотропне дихання за С. Грофом як засіб, що поєднує дихання й музику та виступає засобом енергетизації й каналізації переживань людини з метою тілесного відреагування «емоційних заноз» та відкриття їх смислів) [3];

- базові навики, які забезпечують неперервність цілісного процесу структурування внутрішнього досвіду особистості клієнта, від встановлення контакту до активізації сильних його сторін і позитивного самопрогнозування;

- фактори впливу, які залежать від досвіду й особистості психолога-консультанта та визначають не конкретні засоби впливу, а його зміст: послаблення напруги; розширення репертуару реагування; зміну поведінкових стереотипів за допомогою нового емоційного досвіду; усвідомлене ставлення до нових форм поведінки тощо.

Виокремлення внутрішніх та зовнішніх маркерів передбачає диференціацію одиниць їх оцінки, які можуть бути використані як досліджувані ознаки з метою перевірки результативності дії синергетично-реорганізаційного алгоритму. Одиниці оцінки - це показники, вибір яких зумовлений предметною спрямованістю екзистенціально-системного кон- 
цепту забезпечити реорганізацію смислової динаміки свідомості особистості через повторювальні патерни "співвіднесення зі світом» та «самовіднесення», кожен з яких запускає структурні зміни в системі. До одиниць оцінки віднесено:

1) знаходження автентичної внутрішньої позиції щодо певної ситуації;

2) набуття засобу виразу себе (смисл $\rightarrow$ новий патерн) у відповідності до внутрішньої позиції й реальної ситуації та прийняття викликів життя;

3) оновлення «мнемічного контексту» екзистенції та життєвих відносин (до інших людей, до світу) через налаштування внутрішнього діалогу й залучення всіх пізнавальних контурів переробки переживань (або тілесних відчуттів) - розширення репертуару ментальних репрезентацій;

4) поєднання екзистенції з інтенціальністю, зі «смислом того, що створюємо/виражаємо за допомогою нашого життя», що «актуалізуе множину потенційних наших життів» та відкриває безмежність інтенціальності у переживанні «життєвих парадоксів» [2, с. 217];

5) зняття контекстуальних обмежень парафернальних емоцій (звичні патерни, зокрема, сумніви та страх - старий аттрактор), розвинення сенситивності та визначення ресурсного стану через сприйняття відомого як нового з вивченням (інтерес) та креативним переключенням (подив);

6) відкриття парадоксальних смислів (новий аттрактор) як квантів «картини світу» та формування нових комбінацій особистих концептів, вибудовуючи структуру й якість взаємозв'язків (узгоджені - неузгоджені, анахронічні - нові, одноманітні - варіативні, стандартні - оригінальні) між знайденими смислами раніше сформованого смислового поля та зумовлюючих його мнемічних контекстів щодо елементів системи, яка актуально задіяна.

Синергетично-реорганізаційний алгоритм екзистенціально-системного концепту дає змогу у кожному конкретному випадку макрогенезу «картина світу» особистості використати за принципом достатності та необхідності відповідний діагностико-корекційний метод або комбінацію методів, які окреслять зазначені одиниці оцінки.

Висновки 3 проведеного дослідження. Макрогенез «картини світу» означає динамічний рух смислової конструкції, який зумовлюється процесом розуміння свідомістю власного «тексту» через відношення до нього і розвитком власних значень за рахунок варіативного інтерпретування відкритих раніше смислів. Зазначена дія розуміння $є$ інструментом моделювання зовнішньої реальності та розширення «тунелю» сприйняття світу клієнтом через спеціально організо- вану (за умови звертання за психологічною допомогою) дію «співвіднесення зі світом» та «самовіднесення». Процесуальність синергетично-реорганізаційного алгоритму базується на трьох ключових підходах до аналізу макрогенезу смислової архітектоніки свідомості особистості: генетико-моделюючого як єдності «самопроєктування» особистості й системи умов її функціонування та розвитку [12, с. 23]; синхронічного, спрямованого на дослідження «життєвого світу» особистості, смислових структур, смислового поля; діахронічного - дослідження історії смислової будови «життєвого світу» і його розвитку, вивчення закономірностей розгортання діяльностей, у межах яких реалізуються життєві смисли та цінності особистості [19, с. 47].

Визначені зовнішні та внутрішні маркери та оціночні одиниці синергетично-реорганізаційного алгоритму об'єднуються в єдину систему, можливості якої дають змогу оцінювати безмежний та різноманітний набір екзистенціальних та системно-динамічних ракурсів, які становлять смислове поле та визначають глибину відображення реального світу та специфіку суб'єктивної «картини світу» особистості, зокрема:

- уявлення про світ, сутнісний, ядерний образ якого сприймається як єдиний і цілісний або віддається перевага певному дихотомічному полюсу, наприклад: як джерело можливостей або прояв розподілу, боротьби і відстороненості;

- уявлення про ставлення оточуючих, що становлять системи (батьківську, родинну, професійну, дружню тощо);

- уявлення про життєві події та їх ланцюг, який вибудовується в життєву та особисту історію;

- тілесні відчуття (симптоми) через те, що психічне і тілесне - дві форми прояву єдиних базисних параметрів структури, переплетених у цілісність людини;

- якість емоційних станів, сила та їх модальність як критерії життя в потоці;

- тенденції повторюваної поведінки (патернів), які залежать від ускладнень свідомо керувати певними емоціями з емоційного спектра.

Подальший дослідницький інтерес полягає в обґрунтуванні психолого-педагогічної матриці макрогенезу «картини світу» майбутніх психологів-консультантів та перевірці ефективності програми її реалізації.

\section{ЛІТЕРАТУРА:}

1. Агафонов А.Ю. Основы смысловой теории сознания. Санкт-Петербург : Речь, 2003. 296 с.

2. Бьюдженталь Дж. Искусство психотерапевта. Санкт-Петербург : Питер, 2001. 304 с.

3. Гроф С. Путешествие в поисках себя. Москва : ACT, 2008. 352 c. 
4. Каліщук С.М. Системне моделювання як інтегративний метод особистісних змін й усвідомлення багатоваріативності життєвої реальності. Актуальні проблеми психології : збірник наукових праць Інституту психології імені Г.С. Костюка. Психологія навчання. Генетична психологія. Медична психологія. Київ, 2018. Том Х. Вип. 31. С. 55-64.

5. Каліщук С.М. Суб'єктивна модель реальності: першоджерела побудови. Проблеми сучасної психології : збірник наукових праць Кам'янець-Подільського національного університету імені Івана Огієнка, Інституту психології імені Г.С. Костюка НАПН України. Кам'янець-Подільський : Рута, 2020а. Вип. 47. С. 93-118. DOI: 10.32626/2227-6246 .2020-47.93-117.

6. Каліщук С.М. Площина транстеоретичного екзистенціально-системного концепту реорганізації смислової архітектоніки свідомості особистості. Психологічний часопис : збірник наукових праць Інституту психології імені Г.С. Костюка НАПН України. Tом 6. Вип. 4. Киів. 2020б. DOI: 10.31108/1.2020.6.4.9.

7. Леонтьев А.Н. Психология образа. Вестник Московского университета. Серия 14. Психология, 1979. № 2. C. 3-13.

8. Леонтьев Д.А. Синергетика и личность: к неравновесной персонологии. Методология и история психологии. 2018. Вып. 3. C. 96-104. DOI: 10.7868/ S1819265318030068.

9. Лэнгле А. Терапевтический случай нахождения собственного Я (применение метода персонального экзистенциального анализа). Психология. Журнал высшей школы экономики, 2005. Т. 2. № 2. С. 22-42.
10. Маланов С.В. Генетический анализ психологических явлений в теоретическом контексте системно-деятельностной культурно-исторической психологии. Методология и история психологии, 2018. Вып. 3. C. 47-61. DOI: 10.7868/S1819265318030032.

11. Максименко С.Д. Життєвий шлях особистості як базова категорія генетичної психології. Збірник наукових праць. Психологічні науки. Вип. 2.12 (103). С. 5-13.

12. Максименко С.Д. Генезис существования личности. Киев : КММ, 2006. 240 с.

13. Морен Э. Метод: Природа природы. Москва : $\mathrm{Kaнон}+$, 2013. 464 c.

14. Павленко О.В. Життєва перспектива та індивідуальний досвід як аспекти проблематики життєвого шляху особистості. Вісник Харківського національного університету. Серія «Психологія», 2014 № 1121. C. 28-33.

15. Прохазка Дж. \& Норкросс Дж. Системы психотерапии. Для консультантов, психотерапевтов и психологов. Санкт-Петербург : Прайм-ЕВРОЗНАК, 2007. 383 c.

16. Серкин В.П. Методы психологии субъективной семантики и психосемантики. Москва : Пчела, 2008. 382 c.

17. Смирнов С.Д. Мир образов и образ мира. Вестник Московского университета. Серия 14. Психология, 1981, № 2. С. 15-29.

18. Чиксентмихайи М. Эволюция личности. Москва : Альпина нон-фрикшн, 2017. 420 с.

19. Цапкин В.Н. Единство и многообразие терапевтического опыта. Москва : МГППУ, 2004. 199 с. 